Article

\title{
Urban Green Space Suitability Evaluation Based on the AHP-CV Combined Weight Method: A Case Study of Fuping County, China
}

\author{
Zhiming $\mathrm{Li}^{*}$, Zhengxi Fan and Shiguang Shen \\ College of Landscape Architecture, Nanjing Forestry University, Nanjing 210037, China; \\ fanzx0058@njfu.edu.cn (Z.F.); shensg@njfu.edu.cn (S.S.) \\ * Correspondence: lizhiming7507@njfu.edu.cn
}

Received: 17 June 2018; Accepted: 25 July 2018; Published: 28 July 2018

\begin{abstract}
Urban green space (UGS) provides critical ecosystem services and alleviates environmental problems caused by rapid urbanization. The Analytic Hierarchy Process (AHP) method is recognized as a traditional technique to identify the weight of the UGS suitability evaluation. We reveal the limitations of the AHP method for its subjectivity and uncertainty. Then, we introduce the AHP and coefficient of variation (AHP-CV) combined weight method to better evaluate the suitability of UGS. Based on the principle of minimum information entropy, the AHP-CV combined weight method takes advantage of both the AHP and CV methods, thus keeping a good balance between subjectivity and objectivity. We used the green space system planning of Fuping County in China as a case study. A new evaluation index system was established using 4 aspects. Our results show that high-suitability areas are mainly distributed around the northern mountainous regions, 2 important rivers and the outer areas of the central city. By comparing the UGS suitability evaluation results obtained by the AHP, CV, and AHP-CV combined weight methods, we found that the AHP-CV method was optimal. Therefore, the AHP-CV combined weight method will not only enrich spatial Multi-Criteria Decision-Making techniques but also have a wide application in the related fields of land-use planning.
\end{abstract}

Keywords: green space system planning; ecological suitability evaluation; GIS; AHP-CV combined weight

\section{Introduction}

Since China's rapid urbanization has caused urban sprawl and the decrease of urban green space, the urban ecological environment is under tremendous pressure [1]. Urban Green Space (UGS), an urban biological filter that absorbs pollutants and release oxygen [2-4], provides important ecosystem services that contribute to the quality of life in cities [5-8]. Determining suitable locations for UGS is the primary task of improving the urban ecological environment [9-11].

Ecological suitability evaluation is an important quantitative analytic method for ensuring sustainable land use [12-14], and can be understood as the process of assessing the potential of land development. It provides the basis for scientific decision-making for the rational use of land resources [15-17]. In the 1960s, ecological suitability evaluation was first proposed by landscape architect McHarg [18]; this method has become the basis for land-use planning. Due to the popularization of the geographic information system (GIS), ecological suitability evaluation has been applied to a wide variety of fields, including urban construction land [19], regional planning [20], agricultural planning [21,22], and greenway planning [23,24]. In many case studies, the Analytic Hierarchy Process (AHP) method was incorporated into GIS-based suitability procedures. Kuang [25] 
introduced GIS technology into the green space system planning to analyze the suitability of green construction land in Beihai City and established a city information system. Uy and Nakagoshi [10] used the AHP method to analyze factors, such as air pollution, existing land use, water, and industrial zones, in the GIS environment and studied the green space system suitability in Hanoi. Mahmoud and El-Sayed [26] suggested a method of green network planning to analyze the ecological suitability of a new Egyptian city and identified suitable sites for developing UGS in a desert environment. The Japanese scholars M'Ikiugu et al. [27] analyzed the UGS through landscape metrics and identified the potential expansion area of UGS through the suitability checklist and proximity buffering carried out in a GIS environment.

In view of the complexity and uncertainty of an urban environment, how to identify the suitable evaluation index weight is a critical step for the UGS suitability evaluation. A number of recent papers have discussed the limitations of the AHP method in dealing with the complexity and uncertainty of the evaluation indicators and proposed a fuzzy comprehensive evaluation method to process uncertain and inaccurate problems [28-31]. However, the fuzzy comprehensive evaluation method has also been criticized for its inefficiency in decision-making [32]. There are basically 2 kinds of methods to identify the index weight. One is to use the subjective weight (SW), and the other is to use the objective weight (OW) [33,34]. SW generally relies on expert knowledge to identify the weight of each index and uses methods such as Delphi [35] and AHP [36]. However, these kinds of methods have a larger subjectivity and arbitrariness. They lack a consideration of the changes in objective conditions. OW is based on the statistical data of the evaluation index, which is based on a profound mathematical theory. These kinds of methods include the coefficient of variation (CV) [37], entropy weight (EW) [38], and principal component analysis (PCA) [39]. Nevertheless, the OW methods are more dependent on objective data and cannot reflect the importance of the expert in determining the weight, which usually results in inconsistencies with the actual situation. Compared with the EW and PCA methods, the CV method is easy to operate and requires less basic data; it can objectively reflect the relative importance of the evaluation index [40]. Therefore, we introduced the AHP-CV combined weight method to better evaluate the suitability of UGS, which takes advantage of both the AHP and CV methods, thus keeping a good balance between subjectivity and objectivity.

The main objectives of this study are (1) to propose the combined weight method of the AHP-CV combination, (2) to establish the suitability evaluation index system in the case study, and (3) to demonstrate the usefulness and benefits of the AHP-CV combined weight method in land-use-related fields.

\section{Study Area and Data}

\subsection{Study Area}

Fuping is located in the Weinan area of Shaanxi Province and belongs to a warm temperate continental semi-humid semi-arid monsoon climate. The annual average sunshine in $2352.3 \mathrm{~h}$ and annual average rainfall is $533.2 \mathrm{~mm}$ per annum, which is mostly concentrated in the months from July to September. Fuping County has a central city and 14 townships under its jurisdiction, with the total area of approximately 1245.99 square kilometers (Figure 1).

Founded during the Qin Dynasty, Fuping has a long history with many cultural relics throughout the county, including 10 state-protected historic sites. In addition, Fuping is rich in tourism resources, especially because of the 5 Tang dynasty tombs distributed in its northern mountains regions. The rivers inside the county belong to the Weyhe River system of the Yellow River Basin, which mainly consist of the Shichuan, Zhao, and Wenquan Rivers. 


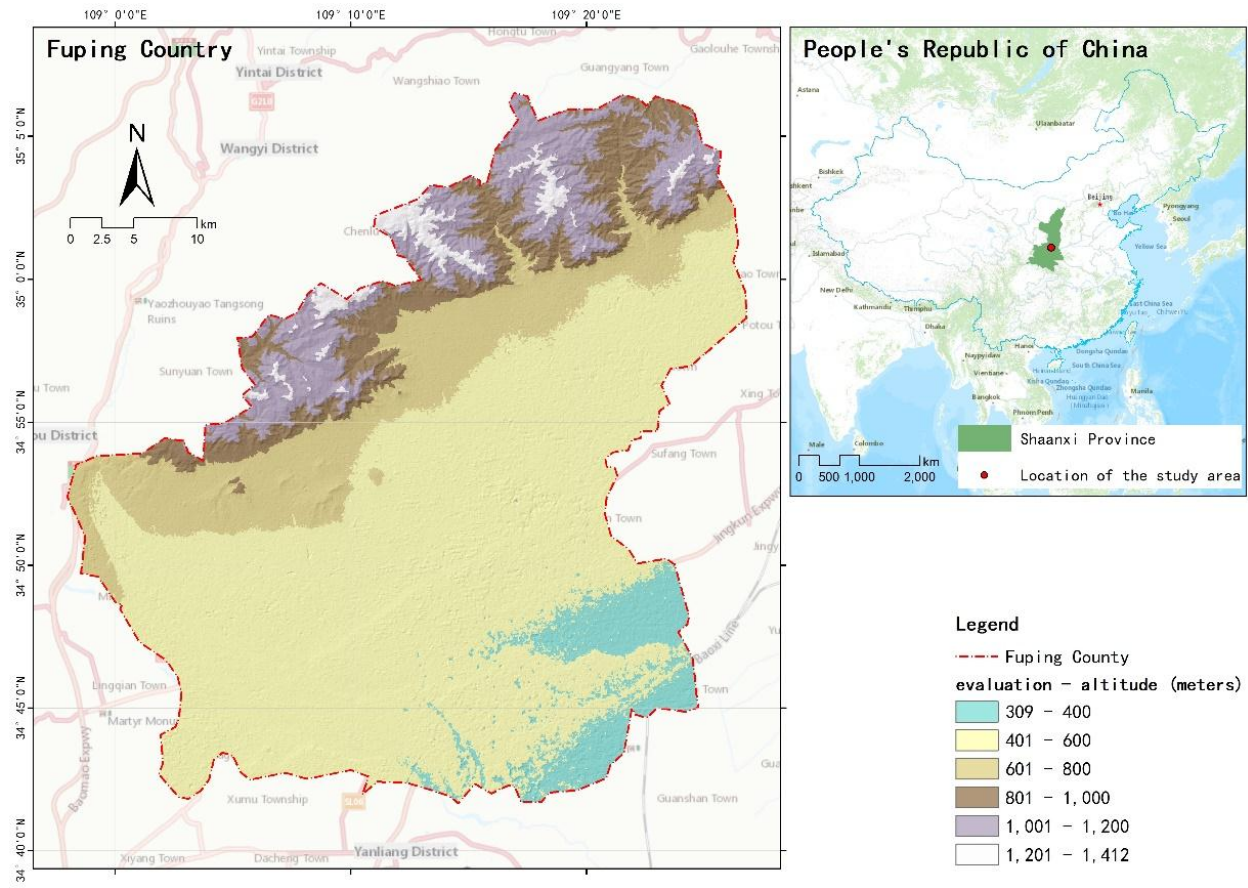

Figure 1. The study area: location and evaluation

\subsection{Data Sources}

The remote sensing image from the 2017 Landsat8 of Fuping (Spatial Resolution $15 \times 15 \mathrm{~m}$, Source: http:/ /www.gscloud.cn/) was used to extract land cover information. Based on the image fusion, correction, and registration of the Landsat8 remote sensing image, the heat island effect and NDVI raster data were obtained by using ENVI5.1. The slope and elevation data were obtained from the GRID digital elevation model (DEM) of the study area, and the DEM was downloaded from the Geospatial Data Cloud (Spatial Resolution $30 \times 30$ m, Source: http:/ /www.gscloud.cn/). The Fuping Urban Master Plan 2015-2030 was obtained from the Planning Bureau of Fuping. The map of the vector data (including the pollution source, significant infrastructure, road traffic, ancient and famous trees, tourism resources, heritage sites, water, geological disasters, and ecological patches) was digitized from the Fuping Urban Master Plan 2015-2030 in ArcGIS10.5.

\section{Methods}

\subsection{AHP-CV Combined Weight}

The development of computer science and fuzzy mathematics has resulted in the evolution of the method for determining the indices weight from a single subjective qualitative technique into a comprehensive objective quantitative technique [41]. At present, the quantitative approaches for determining the index weight in UGS suitability evaluation are mostly single weighting methods. In order to avoid the possible inaccuracy caused by a single weighting method, we used the AHP method to calculate the SW and the CV method to calculate the OW; we combined the 2 kinds of weight information based on the principle of minimum information entropy [42].

1. AHP method for calculating the subjective weight

The AHP method is one of the most commonly used Multi-Criteria Decision-Making (MCDM) techniques that combines the qualitative and quantitative analysis of complex systems [43]. The MCDM preference process requires selected relevant experts to rank the criteria based on pairwise comparisons; these comparisons in our research were obtained by consulting with a team of 20 experts, including 
local residents, officials, and other experts engaged in geography and ecological research. We adopted Saaty's [44] 1-9 scale method to establish pairwise comparisons, which was used to identify the relative importance of each criteria. The consistency check of the pairwise comparison matrix was checked. The consistency check formula is:

$$
R C=I C / I R
$$

If $R C<0.1$, the consistency check result is acceptable, and the weight distribution is reasonable. Conversely, the matrix must be adjusted until the result meets the requirement.

\section{CV method for calculating the objective weight}

The coefficient of variation (CV) is a statistical measure of the dispersion of a probability distribution or frequency distribution [37], i.e., a ratio of the standard deviation to the mean of the evaluation expressed by an amount of variation. In this study, the CV method was used to calculate the objective weight.

We calculated the coefficient of variation:

$$
C_{i}=\frac{\sigma_{i}}{\mu_{i}}
$$

We calculated the weight:

$$
W_{2 i}=\frac{C_{i}}{\sum_{i=1}^{n} C_{i}}
$$

where $C_{i}$ is the coefficient of variation of the evaluation index $i ; \sigma_{i}$ is the standard deviation of the evaluation index $i ; \mu_{i}$ is the average of the evaluation index $i$; and $W_{2 i}$ is the index weight determined by the $\mathrm{CV}$ method.

3. Combination of the subjective and objective weights

We combined the weight $W_{1 i}$ obtained by the AHP and the weight $W_{2 i}$ obtained by the CV method. The combined weight of each evaluation index $W_{i}$ was calculated by the principle of minimum information entropy. The combined method makes full use of the advantage of the AHP and CV methods, and the uncertainty problem caused by a single weighting method was solved. Its formula is:

$$
W_{i}=\frac{\sqrt{W_{1 i} W_{2 i}}}{\sum_{i=1}^{n} \sqrt{\overline{W_{1 i} W_{2 i}}}}
$$

\subsection{UGS Suitability Evaluation Model}

\subsubsection{The Evaluation Index System}

Based on the literature review [36,45-48], we developed an optimized UGS suitability evaluation index framework that included the principles of stability, independence, systematicness, and comprehensiveness in accordance with the actual situation in Fuping County and the availability of the data sources. Evaluation factors were selected from 4 aspects including the human activities, historical sites, natural landforms, and biological protection which should be fully considered in the evaluation process of UGS suitability. Further, the existing land use, pollution sources, significant infrastructure, road traffic, ancient and famous trees, tourism resources, heritage sites, water area, slope, elevation, heat island effect, geological disasters, ecological patches, and NDVI were selected as the most basic factors having a significant impact on the UGS suitability evaluation. Finally, the UGS suitability evaluation index system contains 4 criteria and 16 sub-criteria (Table 1). 
Table 1. UGS suitability evaluation index system.

\begin{tabular}{|c|c|c|c|}
\hline No. & Criteria & Sub-Criteria & Description \\
\hline 1 & \multirow{4}{*}{$\begin{array}{l}\text { Human activities } \\
\qquad(\mathrm{X} 1)\end{array}$} & Existing land use (X11) & Reflects the ecological value of land resources \\
\hline 2 & & Pollution source (X12) & Reflects the degree of pollution impact on the region \\
\hline 3 & & Significant infrastructure (X13) & Characterization of significant infrastructure requires greenbelt isolation \\
\hline 4 & & Road traffic (X14) & Characterizes the basic conditions of green traffic corridors \\
\hline 5 & \multirow{3}{*}{$\begin{array}{l}\text { Historical sites } \\
\quad(\mathrm{X} 2)\end{array}$} & Ancient and famous trees (X21) & Reflects the ecological protection value of ancient and famous trees \\
\hline 6 & & Tourism resources $(\mathrm{X} 22)$ & Reflects the development degree of regional tourism resources \\
\hline 7 & & Heritage sites (X23) & Reflects the ecological and cultural values of heritage sites \\
\hline 8 & \multirow{5}{*}{$\begin{array}{c}\text { Natural } \\
\text { landforms (X3) }\end{array}$} & Water area $(\mathrm{X} 31)$ & $\begin{array}{l}\text { Factors that reflect the conditions of regional water resources and maintenance of } \\
\text { the ecological balance }\end{array}$ \\
\hline 9 & & Slope (X32) & Reflects the degree of impact on vegetation distribution \\
\hline 10 & & Elevation (X33) & Reflects the degree of impact on living creatures \\
\hline 11 & & Heat island effect (X34) & Reflects the influence of regional temperature differences on vegetation \\
\hline 12 & & Geological disasters (X35) & Reflects the stability of the development of green space by geological disasters \\
\hline 13 & \multirow{2}{*}{$\begin{array}{c}\text { Biological } \\
\text { protection }(\mathrm{X} 4)\end{array}$} & Ecological patches (X41) & Reflects the degree of biological diversity \\
\hline 14 & & NDVI (X42) & Reflects the growth of green vegetation \\
\hline
\end{tabular}

\subsubsection{The Classification Criteria for the Evaluation Factors}

We used the determined evaluation index system and local conditions to reclassify the basic impact factors in line with the attribute characteristics and the degree of influence on the evaluation. This study was inspired by the suitability classes proposed by the Food and Agricultural Organization (FAO) [49]. The UGS suitability classification consists of 5 levels and these levels have the numerical values 5, 4, 3, 2 or 1, which represent high-suitability, higher-suitability, medium-suitability, lower-suitability, and low-suitability, respectively (Table 2).

Table 2. The classification criteria for the UGS suitability evaluation factor.

\begin{tabular}{|c|c|c|c|c|c|c|}
\hline \multirow{2}{*}{ Criteria } & \multirow{2}{*}{ Sub-Criteria } & \multicolumn{5}{|c|}{ Layer Classification (Suitability) } \\
\hline & & 5 & 4 & 3 & 2 & 1 \\
\hline \multirow{4}{*}{$\begin{array}{l}\text { Human } \\
\text { activities } \\
\quad(\mathrm{X} 1)\end{array}$} & Existing land use (X11) & Forest, water & Green space & $\begin{array}{l}\text { Agricultural } \\
\text { land }\end{array}$ & - & $\begin{array}{c}\text { Construction } \\
\text { land }\end{array}$ \\
\hline & Pollution source (X12) & $<300 \mathrm{~m}$ & - & $300-500 \mathrm{~m}$ & $500-1000 \mathrm{~m}$ & $>1000 \mathrm{~m}$ \\
\hline & $\begin{array}{c}\text { Significant } \\
\text { infrastructure }(\mathrm{X} 13)\end{array}$ & $<40 \mathrm{~m}$ & - & $40-80 \mathrm{~m}$ & $80-200 \mathrm{~m}$ & $>200 \mathrm{~m}$ \\
\hline & Road traffic (X14) & $<50 \mathrm{~m}$ & - & $50-100 \mathrm{~m}$ & $100-200 \mathrm{~m}$ & $>200 \mathrm{~m}$ \\
\hline \multirow{3}{*}{$\begin{array}{l}\text { Historical } \\
\text { sites }(X 2)\end{array}$} & $\begin{array}{l}\text { Ancient and famous } \\
\text { trees (X21) }\end{array}$ & $<30 \mathrm{~m}$ & - & $30-50 \mathrm{~m}$ & $50-100 \mathrm{~m}$ & $>100 \mathrm{~m}$ \\
\hline & Tourism resources $(\mathrm{X} 22)$ & $<500 \mathrm{~m}$ & $500-1000 \mathrm{~m}$ & $1000-2000 \mathrm{~m}$ & $2000-5000 \mathrm{~m}$ & $>5000 \mathrm{~m}$ \\
\hline & Heritage sites (X23) & Heritage site & $<500 \mathrm{~m}$ & $500-1000 \mathrm{~m}$ & - & $>1000 \mathrm{~m}$ \\
\hline \multirow{5}{*}{$\begin{array}{l}\text { Natural } \\
\text { landforms } \\
\qquad(\mathrm{X} 3)\end{array}$} & Water area $(\mathrm{X} 31)$ & Water & $<100 \mathrm{~m}$ & $100-300 \mathrm{~m}$ & $300-500 \mathrm{~m}$ & $>500 \mathrm{~m}$ \\
\hline & Slope (X32) & $>20^{\circ}$ & $15-20^{\circ}$ & $10-15^{\circ}$ & $5-10^{\circ}$ & $<5^{\circ}$ \\
\hline & Elevation (X33) & $>1000 \mathrm{~m}$ & $800-1000 \mathrm{~m}$ & $600-800 \mathrm{~m}$ & $400-600 \mathrm{~m}$ & $<400 \mathrm{~m}$ \\
\hline & Heat island effect (X34) & $\begin{array}{c}\text { Below the } \\
\text { average } \\
\text { temperature } 4 \\
\text { degrees }\end{array}$ & $\begin{array}{c}\text { Below the } \\
\text { average } \\
\text { temperature 4-3 } \\
\text { degrees }\end{array}$ & $\begin{array}{c}\text { Below the } \\
\text { average } \\
\text { temperature 3-2 } \\
\text { degrees }\end{array}$ & $\begin{array}{c}\text { Below the } \\
\text { average } \\
\text { temperature 2-1 } \\
\text { degrees }\end{array}$ & Other \\
\hline & $\begin{array}{l}\text { Geological disasters } \\
\text { (X35) }\end{array}$ & $\begin{array}{c}\text { Geological } \\
\text { disaster area }\end{array}$ & $>20 \mathrm{~m}$ & $20-40 \mathrm{~m}$ & $40-80 \mathrm{~m}$ & $>80 \mathrm{~m}$ \\
\hline \multirow{2}{*}{$\begin{array}{l}\text { Biological } \\
\text { protection } \\
(\mathrm{X} 4)\end{array}$} & Ecological patches (X41) & $\begin{array}{l}\text { Ecological } \\
\text { patches }\end{array}$ & $>300 \mathrm{~m}$ & $300-500 \mathrm{~m}$ & $500-1000 \mathrm{~m}$ & $>1000 \mathrm{~m}$ \\
\hline & NDVI (X42) & NDVI $>0.3$ & $0.2<$ NDVI $<0.3$ & $0.1<$ NDVI $<0.2$ & $0<\mathrm{NDVI}<0.1$ & $\mathrm{NDVI}<0$ \\
\hline
\end{tabular}

3.2.3. GIS Analysis and Processing of the Evaluation Index Data

To achieve the research purposes, 3 kinds of data processing were needed (Figure 2).

(1) DEM data processing: The DEM data were downloaded from the Geospatial Data Cloud, and the evaluation and slope were obtained from the surface analysis tool in ArcGIS10.5. 
(2) Extract remote sensing image data: After preprocessing the remote sensing images, the existing land use classifications were obtained through the integration of supervised classification and field investigation. The NDVI was derived from the processing of remote sensing image multi-spectral images [50], and the heat island effect was obtained from an algorithm that was applied to retrieve the land surface temperature (LST) distribution from the Landsat8 data [51].

(3) GIS buffer analysis data: Using the classification criteria of the evaluation factor, the different distances of the buffer were established for the pollution sources, significant infrastructure, road traffic, water area and other factors.

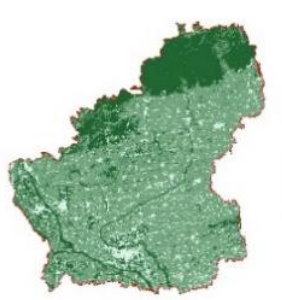

(a)

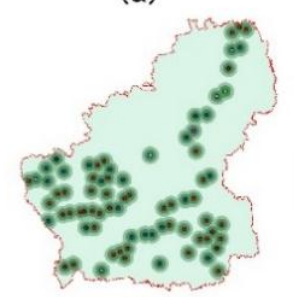

(e)

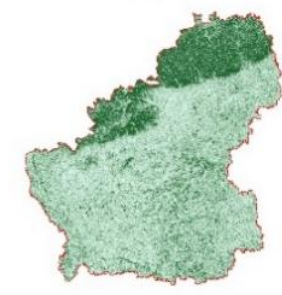

(i)

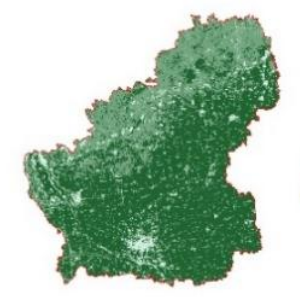

(m)

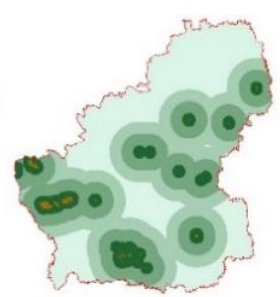

(b)

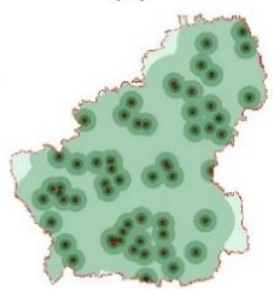

(f)

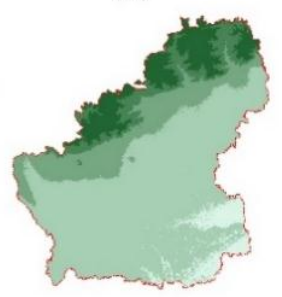

(j)

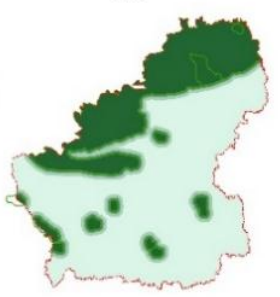

(n)

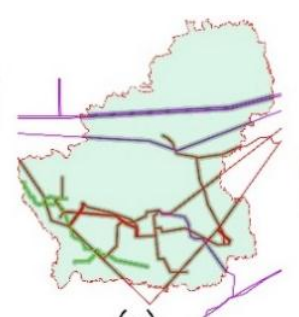

(c)

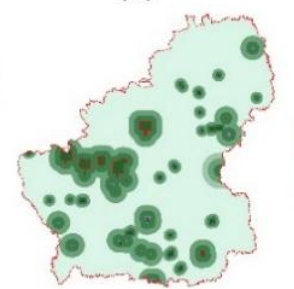

(g)

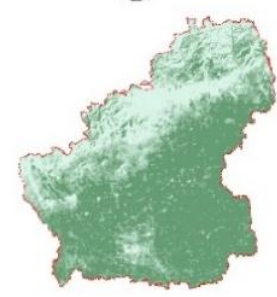

(k)

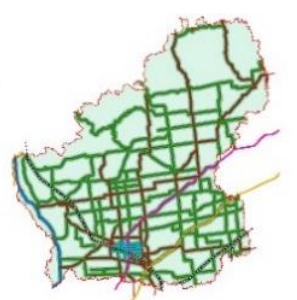

(d)

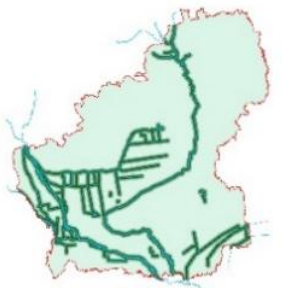

(h)

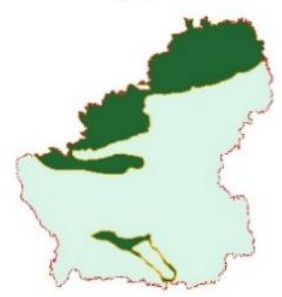

(I)

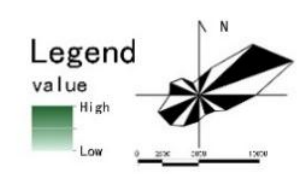

Figure 2. The images of the factor evaluation result: (a) existing land use; (b) pollution source; (c) significant infrastructure; (d) road traffic; (e) ancient and famous trees; (f) tourism resources; (g) heritage sites; (h) water area; (i) slope; (j) elevation; (k) heat island effect; (1) geological disasters; (m) NDVI; and (n) ecological patches.

\subsubsection{Evaluation Index Weight Calculation}

The SW and OW of each evaluation index were identified by the AHP and the CV methods, and the combined weight was identified by the principle of minimum information entropy. There were significant differences among the index weights obtained by different empowerment methods. According to the analysis in Table 3, the weight of the AHP method assumed that the ecological patches, water area, and NDVI were the 3 most important indices among the 14 indices and the 
pollution source was the least important. However, since the AHP method is generally affected by expert knowledge, its weight does not depend on the internal law of the objective data and the index with a larger weight has a greater influence on the overall weight. The CV method regards the NDVI as the most important index, and geological disasters and water area are considered the least important. The CV method is based on the internal law of objective data and may ignore the actual importance of the evaluation indicators. For example, although the weight of the water area should be larger in our study because water is regarded as extremely important to the UGS, the value of 0.0398 calculated by the CV method appears very far from the actual conditions. Therefore, the combined weight method can avoid the disadvantages of the SW and OW methods. This improves the accuracy of the MCDM techniques and offers a more practical value.

Table 3. UGS suitability evaluation index weight and weight ranking.

\begin{tabular}{|c|c|c|c|c|c|c|c|}
\hline Code & Evaluation Factor & $\begin{array}{c}\text { AHP } \\
\text { Weight }\end{array}$ & $\begin{array}{c}\text { AHP } \\
\text { Weight } \\
\text { Ranking }\end{array}$ & $\begin{array}{c}\text { CV } \\
\text { Weight }\end{array}$ & $\begin{array}{l}\text { CV Weight } \\
\text { Ranking }\end{array}$ & $\begin{array}{l}\text { Combined } \\
\text { Weight }\end{array}$ & $\begin{array}{c}\text { Combined } \\
\text { Weight } \\
\text { Ranking }\end{array}$ \\
\hline $\mathrm{X} 11$ & Existing land use & 0.0302 & 11 & 0.0858 & 3 & 0.0568 & 8 \\
\hline $\mathrm{X} 12$ & Pollution source & 0.0174 & 14 & 0.0585 & 7 & 0.0356 & 14 \\
\hline $\mathrm{X} 13$ & Significant infrastructure & 0.0325 & 10 & 0.0534 & 9 & 0.0465 & 10 \\
\hline $\mathrm{X} 14$ & Road traffic & 0.0649 & 5 & 0.0469 & 11 & 0.0616 & 7 \\
\hline $\mathrm{X} 21$ & Ancient and famous trees & 0.0239 & 12 & 0.0541 & 8 & 0.0401 & 13 \\
\hline $\mathrm{X} 22$ & Tourism resources & 0.0477 & 7 & 0.0927 & 2 & 0.0742 & 4 \\
\hline $\mathrm{X} 23$ & Heritage sites & 0.0239 & 13 & 0.0639 & 5 & 0.0436 & 12 \\
\hline $\mathrm{X} 31$ & Water area & 0.1521 & 2 & 0.0398 & 13 & 0.0869 & 3 \\
\hline $\mathrm{X} 32$ & Slope & 0.0427 & 9 & 0.0588 & 6 & 0.0559 & 9 \\
\hline $\mathrm{X} 33$ & Elevation & 0.0519 & 6 & 0.0751 & 4 & 0.0697 & 5 \\
\hline X34 & Heat island effect & 0.0743 & 4 & 0.0502 & 10 & 0.0681 & 6 \\
\hline X35 & Geological disasters & 0.0452 & 8 & 0.0375 & 14 & 0.0459 & 11 \\
\hline $\mathrm{X} 41$ & Ecological patches & 0.2622 & 1 & 0.0414 & 12 & 0.1163 & 2 \\
\hline $\mathrm{X} 42$ & NDVI & 0.1311 & 3 & 0.2419 & 1 & 0.1987 & 1 \\
\hline
\end{tabular}

\subsubsection{UGS Suitability Evaluation Model}

Finally, the UGS suitability evaluation model was established by the Weighted Linear Combination (WLC) procedure. Then, we calculated the comprehensive evaluation value of the UGS suitability by using the raster calculator tool in ArcGIS10.5. The formula is

$$
S=\sum_{i=1}^{n} W_{i} X_{i}
$$

In this formula, $S$ is the comprehensive value of the UGS suitability evaluation; $n$ is the total factor number; $W_{i}$ is the combined weight result of factor $i$; and $X_{i}$ is the suitability value for factor $i$.

\section{Results}

\subsection{Fuping County Green Space Suitability Evaluation Results}

Using the spatial analysis module of ArcGIS10.5, a comprehensive overlay analysis was performed on each evaluation index of Fuping County in accordance with the UGS suitability evaluation model to obtain the final evaluation value. The evaluation value was divided into 5 grades by Naturel Breaks: low-suitability, lower-suitability, medium-suitability, higher-suitability, and high-suitability (Figure 3). The results show that the distribution law of the green space suitability grade in Fuping County is generally high in the north and low in the south, and the urban ecological environment sensitive areas are highly concentrated. The high-suitability area is $164.78 \mathrm{~km}^{2}$, accounting for $13.2 \%$ of the study area. Most of these areas are rivers, lakes, and natural woodlands with a high green area coverage. The higher-suitability area is $229.1 \mathrm{~km}^{2}$, accounting for $18.4 \%$ of the study area. It belongs to the urban surrounding green space with a certain scale and highly concentrated distribution. The medium-suitability area is $260.95 \mathrm{~km}^{2}$, accounting for $20.9 \%$ of the study area. It belongs to a 
more dispersed distribution and is mostly UGS that is built within the city. The lower-suitability area is $357.19 \mathrm{~km}^{2}$, accounting for $28.7 \%$ of the study area. It is mainly the urban construction land with a relatively low building density, serious ecological, and environmental problems, that need to be strengthened by UGS construction. The low-suitability area is $233.97 \mathrm{~km}^{2}$, accounting for $18.8 \%$ of the study area. It is mainly basic protected farmland and the area has a high density of urban construction. In addition to strengthening the protection of basic farmland, it is important to build UGS for all available spaces as far as possible, to improve the urban green coverage.

The most suitable space for the construction of UGS is the area where the ecological environment is most fragile and ecological green space is urgently needed. According to the suitability evaluation results, the most suitable space for UGS distribution is relatively concentrated and mainly distributed in the northwest of woodland mountain area, the Jinshu mountain forest park and other cities in the surrounding hills area, Shichuan river, Zhao river, Wenquan river and other river banks, as well as south of Fuping's central city, Taoyi village, Zan city, and other surrounding parks. Therefore, the construction of UGS should adopt the "concentration and dispersion" spatial organization mode to optimize the layout of green space construction. Using the UGS suitability evaluation, the spatial layout of green space systems can meet traditional qualitative planning requirements and make up for the quantitative analysis that traditional planning has found difficult to achieve. Therefore, it is a more scientific planning scheme than that of the traditional approach.

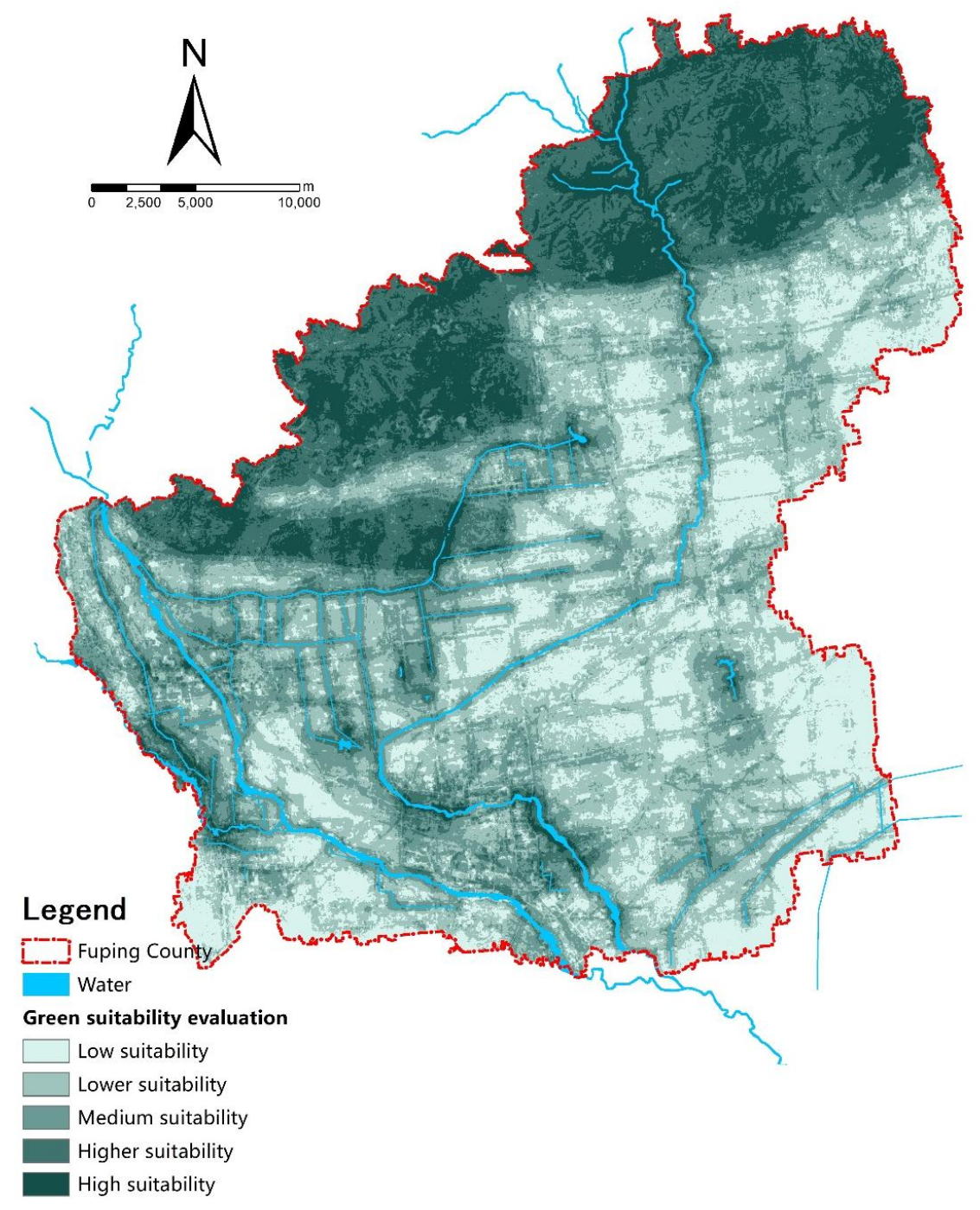

Figure 3. The image of the green space suitability evaluation in Fuping County. 


\subsection{Spatial Layout Optimization of the Green Space System in Fuping County}

The layout of UGS should be integrated, systematic, hierarchical and ecological [52]. Based on the results of the green space suitability evaluation in Fuping County, following the principle of "ecological-priority, people-oriented", and relying on the current situation of green space layout characteristics, we suggested that natural conditions and historical cultural resources should be carefully monitored to maintain the systematization of green space. By managing green space effectively, an integration of the green space system of the city and countryside can be formed, featuring the "district, heart, core, belt, corridor, point and network" (Figure 4).

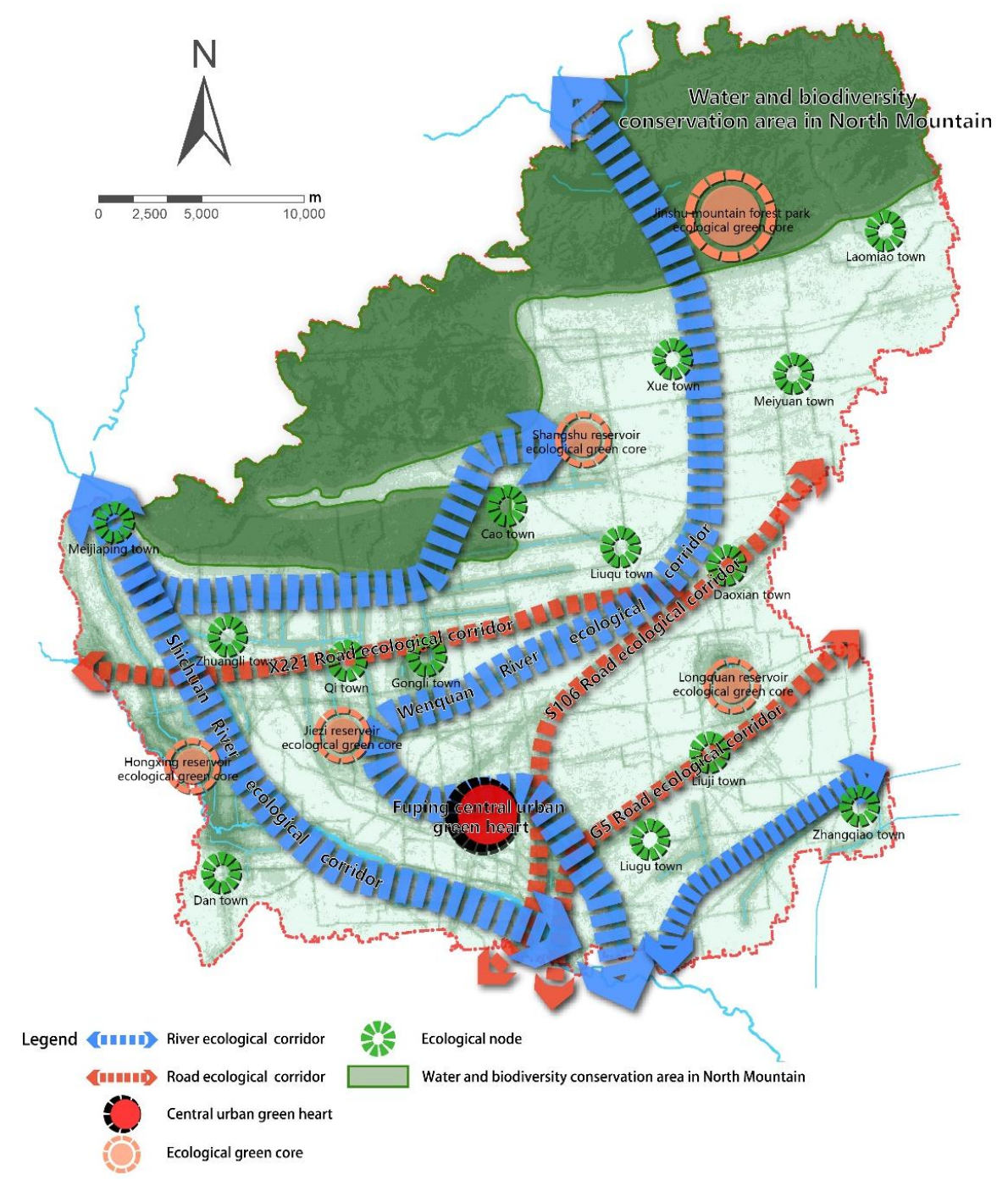

Figure 4. The image of the green space system of Fuping County.

Note: Adapted from the Fuping Urban Green Space System Plan 2017-2030 [53].

Based on the evaluation results, we developed the following suggestions for the spatial layout of the green space system in Fuping County:

1. Protect the conservation of water resources and biodiversity in the northern mountainous regions

In order to improve the ecological environment and strengthen soil and water conservation, natural forest land protection projects should be carried out to improve the forest coverage and forest land quality in these mountainous regions. To strengthen the protection of the local wildlife and their 
habitats, we should strictly control the development of pollution projects and encourage the return of farmland to forests and grasslands.

2. Consolidate the landscape construction of the central city and surrounding towns

In order to improve the quality of the living environment, a "green heart" should be given more weight in the central urban area. We need to accelerate the construction of comprehensive urban parks, special parks, community parks, ribbon parks, street-side gardens, various types of affiliated green spaces, protective green spaces, and other UGS, while expanding the scale of the greening of the surrounding towns and cities.

3. Strengthen the construction of the landscape on both sides of the water and road corridors

By constructing ecological corridors to improve the ecological environment of rivers and roads, we could better connect the natural and human elements of the surrounding areas. By tapping resources with local characteristics and linking them to important green spaces, we could form an ecological network with important functions, like ecological maintenance, sightseeing tours, and recreation and entertainment, while strengthening the continuity of the landscape ecological processes and patterns.

\section{Establish an UGS ecological network}

The green space network is formed by connecting various types of ecological patches through the linear corridor, which can effectively improve the urban ecological environment quality, establish a virtuous cycle of the urban ecosystem, and promote the coordinated development of nature and city [54]. Therefore, by examining the present situation of Fuping green spaces and the results of the green space suitability evaluation, we believe that the central area of Fuping County should build more green spaces, especially in areas with a poor ecological environment quality and serious pollution. More attention should be given to systematicness and consistency of green space system planning. A wedge-shaped landscape can be established to connect open spaces, such as the suburban parks, northern forests, and river, forming an ecological network system of a "green heart-green corridor-green net".

\section{Discussion}

\subsection{AHP-CV Combined Weight of UGS Suitability Evaluation}

Previous studies have proved that the UGS suitability evaluation is critical to UGS location selection [55-58]. However, the evaluation index weight will affect the evaluation results. This case study shows that neither the AHP nor the CV method alone can meet the needs of UGS suitability evaluation in practice. The high-valued evaluation results obtained by the AHP method are more concentrated, and the indicators with a higher weight have a greater impact on the evaluation results (Figure 5a). The CV method relies too much on objective data. Although this method can reflect the actual situation, it ignores the influence of expert knowledge, which can lead to inaccurate results (Figure 5b). Therefore, the AHP-CV combined weight method is a better choice for determining the weight of the index since it takes the advantage of both the AHP and CV methods (Figure 5c). 


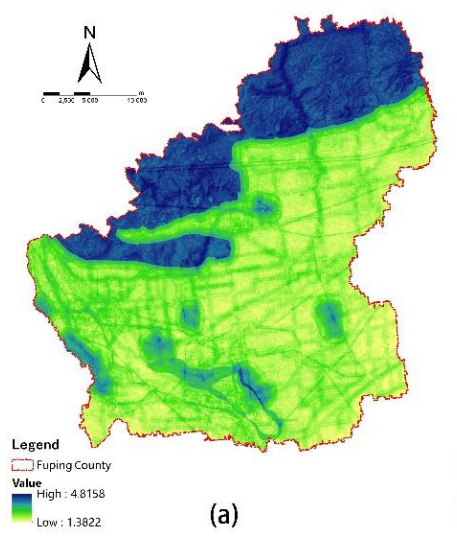

(a)

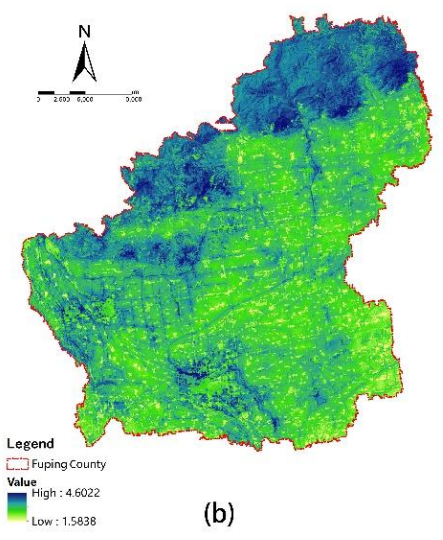

(b)

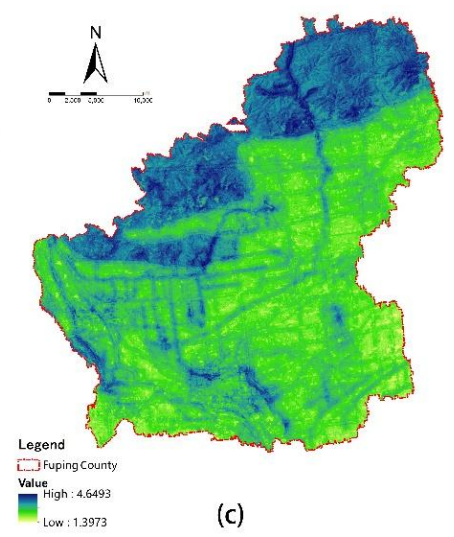

(c)

Figure 5. The images of the evaluation results of the 3 weight methods. (a) AHP method; (b) CV method; and (c) AHP-CV combined weight method.

\subsection{Contributions to the Literature}

Metropolitan green space system planning should not only consider the connection between the elements in urbanized areas but also the connection between the urbanized areas and rural areas in its jurisdiction. Although many studies have shown that suitability evaluation analysis is a common quantitative method in UGS planning $[36,59,60]$, it is not the only one. There are still many studies that use other methods, such as landscape metrics analysis, landscape connectivity analysis, accessibility analysis and network analysis [61-65]. By comparison, given that the AHP-CV combined weight method considers both subjectivity and objectivity, it can quickly and scientifically identify the suitable sites for developing UGS in practice. It is noteworthy that this new method can also be easily applied to other green infrastructure planning studies.

\subsection{Limitations of the Results}

The UGS suitability evaluation is a synthetic and complicated analysis. In practice, due to the diversity of the evaluation indicators and models, complexity of the case being studied, and data available, it is very difficult to find a well-recognized research method for the UGS suitability evaluation. We have innovatively proposed the AHP-CV combined weight method, which not only avoids the possible inaccuracies caused by the single weighting method but also enriches the research in the field of spatial MCDM techniques. However, we acknowledge that this method also has limitations in the evaluation index system and the classification criteria for the evaluation factors. This study is not comprehensive enough in regard to the evaluation index system, especially when examining the regional impact of economic factors; the population data were also not considered. The classification criteria for the evaluation factor were empirical values, which is also a subject worthy of further discussion. This study only explored the static green space suitability in Fuping County, which is just a sectional UGS evaluation suitability. Thus, the study of the dynamics of UGS suitability evaluation will be a research focus in the future.

\section{Conclusions}

The method of UGS suitability evaluation is a key tool to identify suitable locations for UGS planning and construction. Due to this evaluation technique's limitations in terms of its subjectivity and uncertainty, methodological innovation is urgently needed. Thus, we introduced the AHP-CV combined method to determine the weight of the UGS suitability evaluation. By comparing the UGS suitability evaluation results obtained by the AHP, CV, and AHP-CV combined weight methods, we found that our new UGS suitability evaluation method is optimal, as it fully takes the advantage of the SW method while avoiding the deficiencies of the OW method, thus keeping a good balance between subjectivity and objectivity. 
The new UGS suitability evaluation index system was established using 4 aspects of the Fuping green space system. The results show that the high-suitability evaluation areas are mainly distributed around the northern mountainous regions, 2 important rivers, and the outer areas of the central city. Therefore, the local governments should strengthen the planning and construction of UGS and strengthen their coordination with the urban master plan. Four detailed spatial layout suggestions for green space system planning were suggested: (1) protect the conservation of water resources and biodiversity in the northern mountainous regions, (2) consolidate the landscape construction of the central city and surrounding towns, (3) strengthen the construction of the landscape on both sides of the water and road corridors, and (4) establish an UGS ecological network.

In summary, this paper is a scientific attempt to improve the UGS suitability evaluation method. The empirical research has shown that the AHP-CV combined method is an easy operation and efficient technique that can be widely used in the related fields of land-use planning, green infrastructure planning, and transportation and tourism planning.

Author Contributions: Z.L. and Z.F. together conceived the idea and research design of this paper; Z.F. performed data analysis; S.S. acquired the data; Z.L. and Z.F. wrote the paper.

Funding: This research was funded by the National Natural Science Foundation of China (No. 41001086, 31570703), the Six Talent Summit Project in Jiangsu Province (No. 2015-JZ-007), and the Top-notch Academic Programs Project of Jiangsu Higher Education Institutions (PPZY2015A063).

Acknowledgments: The authors greatly appreciate the Planning Bureau of Fuping Country for providing the digital data of the Fuping Urban Master Plan 2015-2030 used in the study. We would also like to thank the reviewers for their helpful comments and suggestions.

Conflicts of Interest: The authors declare no conflict of interest.

\section{References}

1. De Ridder, K.; Adamec, V.; Banuelos, A.; Bruse, M.; Burger, M.; Damsgaard, O.; Dufek, J.; Hirsch, J.; Lefebre, F.; Perez-Lacorzana, J.M.; et al. An integrated methodology to assess the benefits of urban green space. Sci. Total Environ. 2004, 334-335, 489-497. [CrossRef] [PubMed]

2. Wang, B.; Wang, C.; Li, M.; Song, F.; He, P.; Wang, B.; Shi, M.; Qiu, H. Research theories and methods of urban green space at abroad. Chin. J. Ecol. 2006, 25, 857-862. (In Chinese)

3. Haq, S.M.A. Urban green spaces and an integrative approach to sustainable environment. J. Environ. Prot. 2011, 2, 601-608. [CrossRef]

4. Anguluri, R.; Narayanan, P. Role of green space in urban planning: Outlook towards smart cities. Urban For. Urban Green. 2017, 25, 58-65. [CrossRef]

5. Rakhshandehroo, M.; Mohdyusof, M.J.; Tahir, O.M.; Yunos, M.Y.M. The socialbenefits of urban open green spaces: A literature review. Manag. Res. Pract. 2015, 7, 60-71.

6. Li, F.; Wang, R. Research advance in ecosystem service of urban green space. Chin. J. Appl. Ecol. 2004, 15, 527-531. (In Chinese)

7. Wolch, J.R.; Byrne, J.; Newell, J.P. Urban green space, public health, and environmental justice: The challenge of making cities 'just green enough'. Landsc. Urban Plan. 2014, 125, 234-244. [CrossRef]

8. Jim, C.Y.; Chen, S.S. Comprehensive greenspace planning based on landscape ecology principles in compact Nanjing City, China. Landsc. Urban Plan. 2003, 65, 95-116. [CrossRef]

9. Zhou, X.; Wang, Y. Spatial-temporal dynamics of urban green space in response to rapid urbanization and greening policies. Landsc. Urban Plan. 2011, 100, 268-277. [CrossRef]

10. Uy, P.D.; Nakagoshi, N. Application of land suitability analysis and landscape ecology to urban greenspace planning in hanoi, vietnam. Urban For. Urban Green. 2008, 7, 25-40. [CrossRef]

11. Zhou, Y.; Shi, T.; Hu, Y.; Gao, C.; Liu, M. Urban green space land suitability and its spatial distribution in shenyang city of northeast China. Chin. J. Ecol. 2011, 30, 1805-1812. (In Chinese)

12. Malczewski, J. Gis-based land-use suitability analysis: A critical overview. Prog. Plan. 2004, 62, 3-65. [CrossRef]

13. Bojorquez-Tapia, L.A.; Diaz-Mondragon, S.; Ezcurra, E. Gis-based approach for participatory decision making and land suitability assessment. Int. J. Geogr. Inf. Sci 2001, 15, 129-151. [CrossRef] 
14. Li, Q.; Huang, J.; Wang, C.; Lin, H.; Zhang, J.; Jiang, J.; Wang, B. Land development suitability evaluation of pingtan island based on scenario analysis and landscape ecological quality evaluation. Sustainability 2017, 9, 1292. [CrossRef]

15. Zhang, H.; Zhao, Z. Ecological suitability assessment of urban land use based on gis: Synthesis of ecological footprint analysis and eco-system service. Acta Sci. Nat. Univ. Pekin. 2011, 47, 531-538. (In Chinese)

16. Chen, Y.; Yu, J.; Khan, S. Spatial sensitivity analysis of multi-criteria weights in gis-based land suitability evaluation. Environ. Model. Softw. 2010, 25, 1582-1591. [CrossRef]

17. Shearer, K.S.; Xiang, W. Representing multiple voices in landscape planning: A land suitability assessment study for a park land-banking program in concord, north carolina, USA. Landsc. Urban Plan. 2009, 93, 111-122. [CrossRef]

18. McHarg, I.L.; Mumford, L. Design with Nature; American Museum of Natural History: New York, NY, USA, 1969.

19. Marull, J.; Pino, J.; Mallarach, J.M.; Cordobilla, M.J. A land suitability index for strategic environmental assessment in metropolitan areas. Landsc. Urban Plan. 2007, 81, 200-212. [CrossRef]

20. Quan, B.; Zhu, H.; Chen, S.; MJM, R.; Li, B. Land suitability assessment and land use change in Fujian Province, China. Pedosphere 2007, 17, 493-504. [CrossRef]

21. Ngowi, J.; Stocking, M. Assessing land suitability and yield potential for coconuts in tanzania. Appl. Geogr. 1989, 9, 21-33. [CrossRef]

22. Lathrop, R.G., Jr.; Bognar, J.A. Applying gis and landscape ecological principles to evaluate land conservation alternatives. Landsc. Urban Plan. 1998, 41, 27-41. [CrossRef]

23. Miller, W.; Collins, M.G.; Steiner, F.R.; Cook, E. An approach for greenway suitability analysis. Landsc. Urban Plan. 1998, 42, 91-105. [CrossRef]

24. do Carmo Giordano, L.; Riedel, P.S. Multi-criteria spatial decision analysis for demarcation of greenway: A case study of the city of Rio Claro, Sao Paulo, Brazil. Landsc. Urban Plan. 2008, 84, 301-311. [CrossRef]

25. Kuang, P. Suitability analysis for system planning of city open space. Chin. Landsc. Archit. 1995, 11, 48-51. (In Chinese)

26. Mahmoud, A.H.A.; El-Sayed, M.A. Development of sustainable urban green areas in egyptian new cities: The case of el-sadat city. Landsc. Urban Plan. 2011, 101, 157-170. [CrossRef]

27. M'Ikiugu, M.M.; Kinoshita, I.; Tashiro, Y. Urban green space analysis and identification of its potential expansion areas. Procedia Soc. Behav. Sci. 2012, 35, 449-458. [CrossRef]

28. Lai, C.; Chen, X.; Chen, X.; Wang, Z.; Wu, X.; Zhao, S. A fuzzy comprehensive evaluation model for flood risk based on the combination weight of game theory. Nat. Hazards 2015, 77, 1243-1259. [CrossRef]

29. Quinn, B.; Schiel, K.; Caruso, G. Mapping uncertainty from multi-criteria analysis of land development suitability, the case of howth, dublin. J. Maps 2015, 11, 487-495. [CrossRef]

30. Caha, J.; Burian, J. Comparison of Fuzzy AHP Algorithms for Land Suitability Assessment. In Proceedings of the GIS Ostrava, Ostrava, Czech Republic, 22-24 March 2017; Springer: Berlin, Germany; pp. 31-46.

31. Mosadeghi, R.; Warnken, J.; Tomlinson, R.; Mirfenderesk, H. Comparison of fuzzy-ahp and ahp in a spatial multi-criteria decision making model for urban land-use planning. Comput. Environ. Urban Syst. 2015, 49, 54-65. [CrossRef]

32. Saaty, T.L.; Tran, L.T. On the invalidity of fuzzifying numerical judgments in the analytic hierarchy process. Math. Comput. Model. 2007, 46, 962-975. [CrossRef]

33. $\mathrm{Xu}, \mathrm{X}$. A note on the subjective and objective integrated approach to determine attribute weights. Eur. J. Oper. Res. 2004, 156, 530-532. [CrossRef]

34. Jahan, A.; Mustapha, F.; Sapuan, S.; Ismail, M.Y.; Bahraminasab, M. A framework for weighting of criteria in ranking stage of material selection process. Int. J. Adv. Manuf. Technol. 2012, 58, 411-420. [CrossRef]

35. Hayati, E.; Majnounian, B.; Abdi, E.; Sessions, J.; Makhdoum, M. An expert-based approach to forest road network planning by combining delphi and spatial multi-criteria evaluation. Environ. Monit. Assess. 2013, 185, 1767-1776. [CrossRef] [PubMed]

36. Chandio, I.A.; Matori, A.-N.; Lawal, D.U.; Sabri, S. Gis-based land suitability analysis using AHP for public parks planning in Larkana city. Mod. Appl. Sci. 2011, 5, 177. [CrossRef]

37. Guo, Y.; Shen, Y. Quantifying water and energy budgets and the impacts of climatic and human factors in the Haihe River Basin, China: 2. Trends and implications to water resources. J. Hydrol. 2015, 527, 251-261. [CrossRef] 
38. Zhao, L.; Li, L.; Wu, Y. Research on the coupling coordination of a sea-land system based on an integrated approach and new evaluation index system: A case study in Hainan Province, China. Sustainability 2017, 9, 859. [CrossRef]

39. Wu, D.S.; Feng, X.; Wen, Q.Q. The research of evaluation for growth suitability of carya cathayensis sarg. Based on pca and ahp. Procedia Eng. 2011, 15, 1879-1883. [CrossRef]

40. Zhao, W.; Lin, J.; Wang, S.; Liu, J.; Chen, Z.; Kou, W. Influence of human activities on groundwater environment based on coefficient variation method. Environ. Sci. 2013, 34, 1277-1283. (In Chinese)

41. Wu, H.; Yu, H.; Hu, Y.; Meng, F.; Yang, J.; Zhu, J.; Wang, Y. Research on the establishment of the regional ecological security assessment model by means of the combined weights. J. Saf. Environ. 2015, 15, 370-375. (In Chinese)

42. Wu, K.; Jin, J. Attribute recognition method of regional ecological security evaluation based on combined weight on principle of relative entropy. Sci. Geogr. Sin. 2008, 28, 754-758. (In Chinese)

43. Kordi, M.; Brandt, S.A. Effects of increasing fuzziness on analytic hierarchy process for spatial multicriteria decision analysis. Comput. Environ. Urban Syst. 2012, 36, 43-53. [CrossRef]

44. Saaty, T.L. The Analytic Hierarchy Process: Planning, Priority Setting, Resources Allocation; McGraw-Hill: New York, NY, USA, 1980; 281p.

45. Manlun, Y. Suitability Analysis of Urban Green Space System Based on GIS; ITC: Geneva, Switzerland, 2003.

46. Abebe, M.T.; Megento, T.L. Urban green space development using GIS-based multi-criteria analysis in addis ababa metropolis. Appl. Geomat. 2017, 9, 247-261. [CrossRef]

47. Zhou, J.; Zeng, G.; Huang, G.; Li, Z.; Jiao, S.; Tang, L. The ecological suitability evaluation on urban expansion land based on uncertainties. Acta Ecol. Sin. 2007, 27, 774-783. (In Chinese)

48. Liu, B.; Jiang, Y. The inclined errors and countermeasures of urban green space system planning in China; the research on indices system of the urban green space system planning. Urban Plan. Forum 2002, 2, 27-29. (In Chinese)

49. FAO. A Framework for Land Evaluation; FAO: Rome, Italy, 1976.

50. Weber, D.; Schaepman-Strub, G.; Ecker, K. Predicting habitat quality of protected dry grasslands using landsat ndvi phenology. Ecol. Indic. 2018, 91, 447-460. [CrossRef]

51. Kaplan, G.; Avdan, U.; Avdan, Z.Y. Urban heat island analysis using the landsat 8 satellite data: A case study in Skopje, Macedonia. Proceedings 2018, 2, 358. [CrossRef]

52. Zhang, L.; Li, J.; Fu, L. Layout of urban green system: Characteristics and trend. City Plan. Rev. 2009, 3, 32-36. (In Chinese)

53. Fuping Urban Green Space System Plan 2017-2030. Available online: http://www.fuping.gov.cn/ (accessed on 3 July 2018).

54. Liu, B.; Wang, P. Green space ecological network planning: Evolution and research frontier in China. Chin. Landsc. Archit. 2010, 26, 1-5. (In Chinese)

55. Piran, H.; Maleknia, R.; Akbari, H.; Soosani, J.; Karami, O. Site selection for local forest park using analytic hierarchy process and geographic information system (case study: Badreh county). Int. Res. J. Appl. Basic Sci. 2013, 6, 930-935.

56. Zucca, A.; Sharifi, A.M.; Fabbri, A.G. Application of spatial multi-criteria analysis to site selection for a local park: A case study in the Bergamo Province, Italy. J. Environ. Manag. 2008, 88, 752-769. [CrossRef] [PubMed]

57. Nazeri, Z.; Mirzaee, J.; Rostami, A. Application of analytical hierarchy process in land suitability for forest park location (case study: Ilam County, Iran). J. Biodivers. Environ. Sci. 2014, 4, 301-309.

58. Fu, H.; Fu, G. Land suitability evaluation of urban green space based on gis in haikou. J. Northwest For. Univ. 2016, 31, 291-297. (In Chinese)

59. Tahmasebi, E.; Jalali, M.; Gharehghashlo, M.; Nicknamfar, M.; Bahmanpour, H. Urban park site selection at local scale by using geographic information system (GIS) and analytic hierarchy process (AHP). Eur. J. Exp. Biol. 2014, 4, 357-365.

60. Desai, A.R.; Bhagat, S.S. Analysis of suitable locations of urban green space based on AHP for surat city. J. Recent Act. Infrastruct. Sci. 2018, 2. Available online: http://matjournals.in/index.php/JoRAIS/article/ view /1533 (accessed on 10 June 2018).

61. Li, H.; Chen, W.; He, W. Planning of green space ecological network in urban areas: An example of Nanchang, China. Int. J. Environ. Res. Public Health 2015, 12, 12889-12904. [CrossRef] [PubMed] 
62. Guo, S.; Saito, K.; Yin, W.; Su, C. Landscape connectivity as a tool in green space evaluation and optimization of the haidan district, beijing. Sustainability 2018, 10, 1979. [CrossRef]

63. Kong, F.; Yin, H.; Nakagoshi, N. Using gis and landscape metrics in the hedonic price modeling of the amenity value of urban green space: A case study in Jinan City, China. Landsc. Urban Plan. 2007, 79, 240-252. [CrossRef]

64. Comber, A.; Brunsdon, C.; Green, E. Using a gis-based network analysis to determine urban greenspace accessibility for different ethnic and religious groups. Landsc. Urban Plan. 2008, 86, 103-114. [CrossRef]

65. Cetin, M. Using GIS analysis to assess urban green space in terms of accessibility: Case study in Kutahya. Int. J. Sustain. Dev. World Ecol. 2015, 22, 420-424. [CrossRef]

(C) 2018 by the authors. Licensee MDPI, Basel, Switzerland. This article is an open access article distributed under the terms and conditions of the Creative Commons Attribution (CC BY) license (http://creativecommons.org/licenses/by/4.0/). 